\title{
ANALYSIS OF THE EFFECT OF FIXED ASSETS ON THE STOCK PRICE OF THE COMPANY INDEXED LQ45 ON THE INDONESIA STOCK EXCHANGE
}

\author{
Dwi Urip Wardoyo ${ }^{\text {, Liana Suci Karnila Manurung², Novia Egita Br. Tarigan }}{ }^{3}$ \\ ${ }^{1,2,3}$ Telkom University, Bandung, Indonesia \\ Email: dwiurip@ telkomuniversity.ac.id, lianakarnila@student.telkomuniversity.ac.id, \\ Noviaegitabrtarigan@student.telkomuniversity.ac.id
}

\begin{abstract}
The purpose of this research is to examine the effect of fixed assets and the impact of these variables on stock prices. The population used are companies that are included in the LQ45 index contained in the IDX with a period of 3 years (2018-2020). The number of samples used were 15 companies and used a purposive sampling method using the SSPS (Statistical Package for Social Science) program testing program. The results of this study are fixed assets in the company have a positive effect on shares.
\end{abstract}

Keywords: Fixed Asset, Stock Price.

\section{A. INTRODUCTION}

Company shares are a form of ownership of the wealth of a part of a company that chooses to issue shares. Shares can also be defined as the participation of capital of a person or business entity in a company or limited liability company, where on the participation of the capital, the party who includes the capital can claim income from the company, on the company's assets and also have the right to attend the General Meeting of Shareholders (GMS) to get information on the company's employment prospects.(IDX, 2021).

The level of fluctuation of the stock is a form of circumstances that make investors interested in conducting an analysis of the stock. Investor analysis is an assumption that shows that the better the company's employment prospects will have an impact on the level of return it will receive and that is a basic form of investor understanding in looking at the company's shares that he wants to buy. The impact of investor interest in the shares owned by the company is on increasing the stock price and vice versa. Changes in the rise and fall of stock prices every day do not apply equally to all companies that issue shares. According to Nastalim (2020) Fixed assets are a type of wealth owned by a company that can be purchased by external parties but not for sale but rather as a means of generating income and used to facilitate the company's operations and can be used for more than one accounting period.

It can be concluded that the more purchases of the company's fixed assets will affect the stock price of the company that is increasing as well. Previous research in line with the authors was conducted from researchers. (Tita, 2011), Sales growth has no effect on stock prices. Then on the research Wijaya \& Utama (2014), It explains that fixed assets have no effect on changes in a company's stock price. From the assessment of the previous theory makes the author want to make more observations on the effect of fixed assets on the stock prices of companies included in the LQ45 index from 2018-2020, the use of this object is done because companies that are included in the LQ45 index are the types of companies that are most 
purchased by stock investors and companies listed on LQ45 include several types of companies that can be representative of companies that are other.

\section{B. LITERATURE REVIEW}

\section{Fixed Assets}

In PSAK 16, a fixed asset is a tangible asset used in the production of a company providing goods or services, which is not intended for sale and has a useful life of more than one period with administrative purposes. The company's fixed assets can be used on the part of operations and generate profits or profits for the company. (Andhari \& Sukartha, 2017).

\section{Share Price}

Stock Price is a benchmark that becomes a reference for investors to take decisions in investing into the company. Stock prices are often volatile at any time of the period, and this is influenced by the level of supply and demand in the company. (Dewi \& Suaryana, 2013)

\section{Impact of Fixed Assets on Stock Price}

Assets remain important in the change in stock prices. Companies with large assets are often found in the financial statements of large companies. Fixed assets owned by the company can be a handle for the company that can be used at a time when the company is experiencing difficulties that may be able to lower the stock price. So, when the value of fixed assets owned is increasing, it will also affect the level of the company's stock price. In line with Rini's statement (2021) the company's operational activities can run because it is supported by fixed assets and fixed assets should be given special attention because it can be used by the company within the period. Vonna \& Maulida Vonna (2019) Finding that assets remain positively influential on stock prices.

\section{METHOD}

The methods used in research follow a framework that can make it easier for researchers to carry out their observations because to make a study must be systematic. In (Sekaran, 2016) there are six aspects of research design, in this study includes. What the authors want to do in this study is a form of hypothesis testing, developed from earlier theories and studies. In this research, it formulates the purpose of the study of the impact of fixed assets on the company's stock price. Then the type of investigation that the author use is the study of causality, which aims to find out the causal relationship between independent variables that affect dependent variables. Standard intervention, which is done is minimal intervention. With meaning, that researchers do not manipulate the data used to influence the final result of the data. Unit of analysis, in this study is a type of company that has been registered in Indonesia Stock Exchange and indexed LQ45 in the period 2018-2020. As well as the time period used is the type of horizon used by researcher used is a longitudinal type taken in the period 20182020.

There is this study, the author of the program from SPSS in analyzing and analyzing data, the use of the program is done because SPSS is a statistical program that can analyze statistical data effectively and accurately, as well as give a diverse final result in accordance with the decision-making. The analysis used for hypothesis testing is regression analysis. 
The form of empirical equality that is used to examine the influence of independent variables on dependent variables is: $\mathrm{Y}=\alpha+\beta \mathrm{X}+\mathrm{e}$

Where:

$\mathrm{Y}=$ Share Price

$\mathrm{X}=$ Fixed Assets

$\beta=$ Regression coefficient $\mathrm{X} 1$,

$\alpha=$ Constant

$\mathrm{e}=$ Error

\section{RESULT AND DISCUSSION}

According to the final results obtained by the SSPS program, the results of multiple linear analysis on the following research variables:

Table 1. Model Construction Results Coefficients $^{\mathrm{a}}$

\begin{tabular}{|c|l|c|c|c|c|c|}
\hline \multicolumn{2}{|c|}{} & \multicolumn{2}{|c|}{ Unstandardized Coefficients } & $\begin{array}{c}\text { Standardized } \\
\text { Coefficients }\end{array}$ & \multirow{2}{*}{} & \multirow{2}{*}{ Sig. } \\
\cline { 3 - 5 } \multicolumn{2}{|c|}{ Model } & B & Std. Error & Beta & t & S \\
\hline 1 & (Constant) & 3990.969 & 583.253 & & 6.843 & .000 \\
\cline { 2 - 7 } & Fixed Assets & .009 & .012 & .110 & .718 & .477 \\
\hline
\end{tabular}

a. Dependent Variable: Stock Price

According to the final results obtained by the SSPS program, the results of multiple linear analysis on the following research variables: $Y=3990,969+009 \mathrm{X}+\mathrm{e}$. From the regression equation above, it can be that constant $(\alpha)$ amounted to 3990,969 which means that when the asset remains considered constant, then the size of the stock price is $39,90969 \%$.

Based on a form of testing that has been previously tested, the hypothesis is not accepted if the $\beta=0$, which indicates that the value of the $\beta$ of the asset remains, equal to zero and vice versa the hypothesis is acceptable if the $\beta \neq 0$ is not. The value of the $\beta$ of the asset remains not equal to zero. According to the table above, it can bestated that the asset still has a value of $\beta=009$ which means that each increase of $1 \%$ of the fixed asset rate $(\mathrm{X})$ then the share price (Y) will increase by 009. So, it can be concluded that the hypothesis is accepted, and the asset still has a positive influence on the stock price. The more value of fixed assets that the company has, the greater the tendency of the company to maintain fixed assets in the company's operating system.

This is in the way of Rini's statement (2021) fixed assets must be considered because fixed assets are the company's operational activities that run within a certain period. Fixed assets are a supporting tool of continuity of the company, which contains company assets that can be traded that have a volatile value and there are also corporate assets that cannot be traded where the property is a reflection of the company's ability to maintain the company's operating activities and reference for shareholders to invest in the company and influence on the increase in the stock price (Hasransyah et al., 2018).

The results of the observations state that assets still have a positive influence on the stock price in line with research. Vonna \& Maulida Vonna (2019). However, this study contradicts the research. Wibowo,(2017) which explains that fixed assets negatively affect the stock price. 


\section{E. CONCLUSIONS}

Based on the results of the above analysis and testing, it can be concluded that the company's fixed assets have a positive impact on the share price of LQ45 indexed companies listed on the Indonesia Stock Exchange. For further researchers are expected to use the fixed assets of different companies and not studied in this study, or multiply entities so that the results obtained more optimally are also accurate and may give different research results. And hopefully, for further research can develop other variables that can affect the company's stock price.

\section{REFERENCES}

Andhari, P. A. S., \& Sukartha, I. M. (2017). Pengaruh Pengungkapan Corporate Social Responsibelity, Profitabilitas, Inventory Intensity, Capital Intensity dan Leverage pada Agresivitas Pajak. E-Jurnal Akuntansi Universitas Udayana, 18(3), 2115-2142.

Dewi, Putu Dina Aristya \& Suaryana, I. G. N. . (2013). Pengaruh EPS, DER, Dan PBV Terhadap Harga Saham. E-Jurnal Akuntansi, 4(1), 215-229.

Faisol, F. (2017). Islamic Bank Financing and It's Impact on Small Medium Enterprise's Performance. ETIKONOMI. https://doi.org/10.15408/etk.v16i1.4404

Hasransyah, G., Asmapane, S., \& Diyanti, F. (2018). Analisis perlakuan akuntansi aset tetap dan pengaruhnya terhadap laporan keuangan. Kinerja, 14(1), 31-39. https://doi.org/10.29264/jkin.v14i1.2447

IDX. (2021). Informasi Umum. https://www.idx.co.id/produk/saham/\#Informasi Umum

Nastalim., A. \& Y. D. H. (2020). Analisis pengaruh profitabilitas dan investasi aset tetap terhadap nilai perusahaan manufaktur (sub-sektor konsumsi) yang terdaftar di bursa efek indonesia pada tahun 2015-2017. Paper Knowledge . Toward a Media History of Documents, 1(2).

Sekaran, U. \& R. B. (2016). International Standard Classification of Occupations (ISCO). Encyclopedia of Quality of Life and Well-Being Research, 3336-3336. https://doi.org/10.1007/978-94-007-0753-5_102084

Tita, D. (2011). Pengaruh Rasio Keuangan, Pertumbuhan Penjualan Dividen terhadap Harga Saham. Jurnal Bisnis Dan Akuntansi, 13(1), 57-66.

Vonna, S. M., \& Maulida Vonna, S. (2019). (2019). Pengaruh Aset Tetap terhadap Harga Saham pada Perusahan yang terindeks LQ45 di Bursa Efek Indonesia. 133-137.

Wibowo, A. \& M. C. (2017). Analisis pengaruh profitabilitas, kebijakan utang, dan struktur aset terhadap harga serta return saham dengan kualitas audit sebagai variabel pemoderasi. Jurnal Manajemen Bisnis, 20(3). https://ibn.ejournal.id/index.php/ESENSI/issue/view/8

Wijaya, I., \& Utama, I. (2014). Pengaruh Profitabilitas, Struktur Aset, Dan Pertumbuhan Penjualan Terhadap Struktur Modal Serta Harga Saham. E-Jurnal Akuntansi, 6(3), 514-530. 